\title{
Exploration of the Building of the Student Party Branch in Higher Vocational Colleges under the Network Environment
}

\author{
GuoHui Su, a \\ ${ }^{1}$ GuangDdong Mechanical \& Electrical College \\ asuguohui@yeah.net
}

Keywords: Network, the Party Branch, Higher Vocational Colleges

\begin{abstract}
With the rapid development of information technology, network is closely related to the college students' daily life. Building the student Party branch in higher vocational colleges under the network environment is a new management model of the Party organization. As a basic part of the organization system of the Party, student Party branch plays an important political role. It also plays a major role in bringing up the qualified talents in the new century. So it is necessary for the Party workers to recognize clearly the effects of the network on the Party construction.
\end{abstract}

\section{Introduction}

With the development of information technology and popularization of internet, internet culture has been deep into all areas of society. It has a strong impact on our thoughts, especially the college students'. Building the student Party branch in higher vocational colleges under the network environment is a new management model of the Party organization. Along with the rapid development of network, the Party workers are facing new problems and challenge. It is also a new opportunity for the student Party construction.

This thesis consists of four parts. At the first part, the author will analyze the influences of the network on the construction of student Party branch. At the second part, the author will stress the necessity of building the student Party branch under the network environment. At the third part, we will explore the methods of building the student Party branch under the network environment. At the last part, we will discuss the problems that we should pay great attentions to.

\section{The Influences of the Network on the Construction of Student Party Branch}

In recent days, with the development and popularization of information technology, the virtual field of network has become a way for the survival and development of the Party in vocational colleges. It is also the main place for the study and life of college students. The young students have become the main group for the survival and development of virtual field of network. The virtual field of network has both positive and negative effects on college students. It is a severe test for the construction of the Party in the colleges. On one hand, the virtual field of network is good for the formation and development of the way of thinking. The alternation of the real social field and virtual field is good for the development of the multidimensional three-dimensional way of thinking. It's also good for the exploitation of potential and the fostering of scientific spirits. Besides, it benefits the establishment of the new study view and the improvement of learning efficiency. What is more, it offers the college students quantity of quality information instantly and conveniently. Meanwhile, timeliness and effectiveness are the two characteristics of the network technology. These not only guarantee the Party's policies get published in time so as to make the Party members understand its essence thoroughly, but also ensure that the Party organization can listen to the real voice of the grass-roots party members and know about the situation of the Party construction. On the other hand, there are all kinds of information on the network. Some are healthy and positive. Some are false, pornographic and violent which are bad for the student's ethics. Besides, the hostile forces try to westernize and divide our country by releasing some false information that impairs the state's security and social stability. All these have negative impact on the immature students. 
Besides, the network has weakened the influences of the Party branch. The traditional forms of the Party branch are meetings, conversations and reports and so on. The students get information and get educated in these ways. The new way is both opportunity and challenge for the construction of the Party.

$\mathrm{Hu}$ Jingtao stresses that it is important to study the effects of internet on teenagers. We must build a new campaign for the ideological and political work and get the success of propaganda education on the network. We must make efforts to make the internet become the new way of acquiring knowledge and getting educated for the youth. Jiang Zeming states that the application of internet makes the information spread more widely, fast and effectively. We must follow the trend as well as update and strengthen the means of information dissemination positively. Thus, when referring to the construction of the Party at the colleges, we must pay great attention to the virtual field. We must realize that the network is crucial for the consolidating the Party's ruling status and the Party building in higher vocational colleges.

\section{The Necessity of Building the Student Party Branch under the Network Environment}

The development and popularization of information has changed our way of study and life. As to the building of the Party branch at colleges, the internet also plays an indispensable role. The author will explain the necessity of building the student Party branch under the network environment as follows.

(1)It is the need of the higher education. The higher vocational college is one of the modes of higher education. It is also the component of our socialism education system. Besides, it is the need of education with socialist characteristics. The Party branch is the political core of the Party organization. It is also the bridge and bond between the Party and students.

(2)It is the demand of the students' development of ideology and morality. Most of the college students are active and rebellious. They think they are mature but actually they are not. Although they have some ability to discriminate what is right and what is wrong, they are easy to be influenced by the western culture and the environment. Comparing with the ordinary students, the student Party members are more positive and mature. They set an example for the ordinary students.

\section{The Methods of Building the Student Party Branch under the Network Environment}

Building the student Party branch under the network environment is an urgent and heavy task. The Party workers must unite together and promote the destruction of the Party branch at the college positively. At first, the Party workers must accept and follow the new trend and update their concept. Besides, they should try their best to broaden the field of Party construction on the network and occupy the internet as the field of ideological education. The network has supplied the construction of the Party with abundant resources and new work space. It is also a bridge and bond for the understanding and communication between the Party organization and the student Party members. As a new communication media, it integrates words, sounds, picture, images and videos so as to make the information shared globally. The Party workers at colleges should make full use of the platform to advocate the Marxist theory and the theory of socialism with Chinese characteristics. Nowadays, many higher vocational colleges have set up the online Party schools, the online Youth League schools. The web-based Party school system is efficient software to reform the traditional teaching mode and improve the information level of the political education. But, for the objective limits of financial resources, material resources and manpower, there have not been higher-level technology platform such as special websites for the Party construction. While there is other ways we can choose. For example, the school I work at has started to explore network construction. Except for the Party branch QQ group, it also set up the blog among the Party members. This attempt is warmly welcomed by most of the students.

Web log is the fourth- generation communication media after E-mail, BBS and QQ. It provides a new platform for people to express their voice freely and deliver information conveniently. The students can know about the latest news of the Party and the Party branch through the Web log. 
Besides, they can share their ideas with each other, which absolutely is good for the enhancement of cohesive force of the Party branch. The Party branch can foster activists, recruit new Party members through the Web blog. Moreover, we can get to know the students' life and the heated topic they focus on so as we can spread the right political conception and the socialist values. We can also carry forward the advanced deeds and set up models. Compared with the traditional methods of Party construction, the interaction function of Web log is more powerful.

\section{The Problems That We Should Pay Great Attentions to}

In the information age, we are enjoying the convenience of the website as well as suffering the negative effects. There are some problems that we should pay great attentions to.

(1)We should not only value the construction of the Party branch in our thoughts, but also update our concept in time. We should fully recognize that network is a new and crucial platform for the Party construction. The Party organization must attach great attention to the construction of information and the network.

(2)We should stress the combination of network Party branch and the entity Party branch. They coexist and complement each other. We cannot say that the level of one is higher than the other. The difference is that they play a role through different medium. On one hand, the entity Party branch is the basis of the network Party branch. On the other hand, network Party branch is the expansion and extension of the entity Party branch. They together constitute the mode of the Party construction under the network environment.

(3)We should stress the combination of the two natures: opening and confidentiality. As we know, internet is so opening that any other medium cannot compare with. While, there are many secrets in the work of the Party construction. With the development of network technology, the safety of the network is facing severe challenges.

\section{Conclusions}

The basic level of the Party's organization in colleges and universities is the base of the whole work. The Party workers should realize the importance of building the Party branch under the environment of network. The author believe that as long as we make full use of the network and avoid the bad effects, the construction of the Party branch will be much easier and more efficient.

\section{References}

[1] ZM. Wang: Journal of Hebei University of Economy and Trade, Vol. 20 (2001).7, p.115.

[2] J. Zhang: Journal of School Party Construction and Ideological Education, Vol. 31 (2006).11, p. 26.

[3] F. Wang: Journal of Higher Education in Chemical Engineering, Vol. 23 (2005).2, p.55.

[4] J. Bai: Journal of Ideological \& Theoretical Education, Vol. 34 (2007).3, p.59.

[5] X. Zhou: Journal of School Party Construction and Ideological Education, Vol. 12 (2009).07. p.35.

[6] Y. Zheng: Higher Education Exploration, Vol. 21 (2010). 10. p.47. 